\title{
The effect of temperature and irradiance on the growth and carotenogenic capacity of seven strains of Dunaliella salina (Chlorophyta) cultivated under laboratory conditions
}

\author{
PATRICIA I. GÓMEZ and MARIELA A. GONZÁLEZ
}

Laboratorio de Ficología, Departamento de Botánica, Facultad de Ciencias Naturales y Oceanográficas, Universidad de Concepción, Concepción, Chile.

\begin{abstract}
The carotenogenic microalga Dunaliella salina is cultivated as a natural source of $\beta$-carotene. The 9-cis isomer of $\beta$-carotene is found only in natural sources having commercial advantages over the all-trans isomer due to its high liposolubility and antioxidant power. High irradiance appears to stimulate specifically all-trans $\beta$-carotene accumulation in D. salina, whereas low temperature apparently elicits $\alpha$-carotene and 9-cis $\beta$ carotene production. We studied the effect of temperature and irradiance on the growth and the carotenogenesis of three Chilean (CONC-001, CONC-006 and CONC-007) and four non-Chilean (from Mexico, China, Australia and Israel) strains of D. salina cultivated under two photon flux densities (40 and $110 \mu \mathrm{mol}$ photons $\left.\mathrm{m}^{-2} \cdot \mathrm{s}^{-1}\right)$ and two temperatures $\left(15\right.$ and $\left.26^{\circ} \mathrm{C}\right)$. The Chilean strain CONC-001 and all of the non-Chilean strains exhibited the highest growth rates and the maximum cell densities, whereas the Chilean strains CONC-006 and CONC-007 showed the lowest values in both parameters. The Australian strain showed the highest accumulation of total carotenoids per unit volume $\left(40.7 \mathrm{mg} \cdot \mathrm{L}^{-1}\right)$, whereas the Chilean strains CONC-006 and CONC-007, the only ones isolated from Andean environments, yielded the highest amounts of carotenoids per cell (61.1 and $92.4 \mathrm{pg} \cdot \mathrm{cell}^{-1}$, respectively). Temperature was found to be more effective than irradiance in changing the qualitative and quantitative carotenoids composition. The Chilean strains accumulated 3.5 -fold more $\alpha$-carotene than the non-Chilean strains when exposed to $15^{\circ} \mathrm{C}$ and, unlike the non-Chilean strains, also accumulated this pigment at $26^{\circ} \mathrm{C}$. The 9 -cis/all-trans $\beta$-carotene ratio was $>1.0$ in all treatments for all strains, and the values were not greatly influenced by either temperature or photon flux density. Physiological and biotechnological implications of these results are discussed.
\end{abstract}

Key terms: Dunaliella salina strains, growth, $\alpha$-carotene, $\beta$-carotene, temperature, irradiance.

\section{INTRODUCTION}

Dunaliella salina Teodoresco is a green microalga recognized at present as the most salt-tolerant eukaryote known. Under growth-limiting conditions, some strains of D. salina can accumulate more than $10 \%$ of their dry weight in $\beta$-carotene (Ben-Amotz et al., 1982; Ben-Amotz \& Avron, 1983b; Borowitzka \& Borowitzka, 1988), giving rise to the richest natural source of this pigment known so far.

$\beta$-carotene is marketed as a food coloring agent, as pro-vitamin $\mathrm{A}$ in food and animal feed, as an additive to cosmetics, for multivitamin preparation and, in the past decade, for its purported anti-oxidant properties. At present, most of the commercially available $\beta$-carotene is produced synthetically. Unlike synthetic $\beta$ carotene, which is composed solely of the all-trans isomer, the $\beta$-carotene of $D$. salina also includes the 9-cis isomer (Ben-Amotz et al., 1982; 1988). The higher liposolubility and antioxidant activity of the latter explains the increasing demand for the pigment derived from this microalga (Borowitzka \& Borowitzka, 1989; Ben- 
Amotz \& Avron, 1989; 1990; Palozza \& Krinsky, 1992; Jiménez \& Pick, 1993; Becker, 1994; Levin \& Mokady, 1994; BenAmotz \& Levy, 1996). Furthermore, some strains of $D$. salina also accumulate $\alpha$ carotene, which is a pigment that only recently is receiving attention due to its anti-oxidant and anti-carcinogenic properties (Challem, 1997). It has been stated that $\alpha$-carotene is more effective than $\beta$-carotene in suppressing experimental carcinogenesis (Murakoshi et al., 1992) and also that the intake of this pigment in the human diet helps to reduce the incidence of lung cancer in smokers (Heber, 2000) and ovarian cancer in postmenopausal women (Cramer et al., 2001).

It is already known that the massive accumulation of $\beta$-carotene in $D$. salina is triggered by environmental stresses such as intense irradiance, high salinity, nutrient starvation and extreme temperatures (BenAmotz et al., 1982; Ben-Amotz \& Avron, 1983a; Borowitzka et al., 1984). Less information exists on the influence of these parameters on $\alpha$ - and $\beta$-carotene cell proportion and in the $\beta$-carotene isomers ratio. In this respect, Ben-Amotz (1996) found in $D$. bardawil (nomen nudum of $D$. salina according to Borowitzka and Borowitzka, 1988) that decreasing the culture temperature from $30^{\circ} \mathrm{C}$ to $10^{\circ} \mathrm{C}$ caused a four-fold increase in the 9-cis/alltrans $\beta$-carotene ratio $(0.5$ to 2.0$)$, with no significant changes in the other cell pigments. Given the superior liposolubility of 9 -cis $\beta$-carotene, this author explains the preferential accumulation of this isomer as a protective mechanism against the crystallization of $\beta$-carotene at low temperatures.

Although $\alpha$-carotene has been detected in D. salina (in CONC-001 and CONC-006, Markovits et al., 1993; in D. bardawil, BenAmotz, 1996), conditions that stimulate its accumulation are poorly understood. Orset and Young (1999) analyzed the effect of temperature on the accumulation of $\alpha$ carotene in a strain of D. salina (CCAP 19/ $30=D$. bardawil), detecting a 7.5-fold increase in the levels of $\alpha$-carotene when the temperature was decreased from 34 to $17^{\circ} \mathrm{C}$, whereas the levels of $\beta$-carotene were unaltered. These results are in conflict with those obtained by Ben-Amotz (1996) for the same strain that did not detect any change in $\alpha$-carotene content in cells growing either at $30^{\circ} \mathrm{C}$ or at $10^{\circ} \mathrm{C}$.

Furthermore, it has been demonstrated that the accumulation level of $\beta$-carotene as well as its 9-cis/all-trans isomers ratio depend on the integral light intensity to which this microalga is exposed during a division cycle (Ben-Amotz \& Avron, 1983a; Ben-Amotz et al., 1988). There is little doubt regarding the photostimulation of $\beta$-carotene biosynthesis in D. salina; however, it is not clear as to whether high or low irradiance is more effective in stimulating synthesis of 9 -cis $\beta$-carotene (Ben-Amotz et al., 1988; Jiménez \& Pick, 1994; Orset \& Young, 2000).

Since Parra and colleagues (1990) reported the presence of $D$. salina in Chile, several Chilean research groups have performed studies that have shown that strains of $D$. salina differ greatly in their physiological (Cifuentes et al., 1992; 1996a; 1996b; Markovits et al., 1993; Gómez et al., 1999) and genetic attributes (González et al., 1999; Gómez \& González, 2001; González et al. 2001), even when collected from geographically proximate locations. Among the eight Chilean strains of $D$. salina studied to date, three strains demonstrate physiological attributes with industrial potential: CONC-001 from the coastal saline lagoon, La Rinconada, shows high growth rate; CONC-006 and CONC007 from the Andean saline ponds, Salar de Atacama, demonstrate high total carotenoids/cell (Cifuentes et al., 1992; 1996b; Gómez et al., 1999).

Considering that the natural 9-cis isomer produced by $D$. salina is a more potent antioxidant than the all-trans (Palozza \& Krinsky, 1992; Jiménez \& Pick, 1993; Becker, 1994; Levin \& Mokady, 1994; BenAmotz \& Levy, 1996) and $\alpha$-carotene is a more effective antioxidant and anticarcinogenic agent than $\beta$-carotene (Murakoshi et al., 1992; Challem, 1997; Heber 2000; Cramer et al., 2001), it makes sense to concentrate on identifying the strains that naturally produce more of these pigments as well as on studying the 
environmental factors that trigger their accumulation.

In this study, we compared the physiological response of seven strains (three from Chile and one each from Australia, Mexico, China and Israel) of $D$. salina already used or with potential applicability in commercial mass cultures, grown under four different treatment combinations of irradiance (40 and $110 \mu \mathrm{mol}$ $\left.\mathrm{m}^{-2} \mathrm{~s}^{-1}\right)$ and temperature $\left(15\right.$ and $\left.26^{\circ} \mathrm{C}\right)$. The aim of this research was to discover any differences in the total carotenoids amount, $\alpha$ - and $\beta$-carotene proportion, and $\beta$-carotene isomeric ratio between the strains grown under these different irradiance and temperature regimes.

\section{MATERIALS AND METHODS}

\section{Algal strains}

Unialgal cultures of three Chilean (CONC001, CONC-006 and CONC-007), and four non-Chilean (from Mexico, China, Australia and Israel) strains of Dunaliella were used (Table I). All of the strains are maintained at the Microalgae Culture Collection, Universidad de Concepción, Chile.

\section{Culture conditions}

The strains were grown in $250 \mathrm{ml}$ Erlenmeyer flasks containing $150 \mathrm{ml}$ of Provasoli-enriched seawater medium (PES) (McLachlan, 1973; Gómez et al., 2003) supplemented with $12.5 \% \mathrm{w} / \mathrm{v} \mathrm{NaCl}$. The flasks were maintained in culture chambers at constant temperature with continuous light provided from fluorescent day-light tubes, without aeration, and manually shaken twice a day. The strains were grown under the following combined conditions of temperature and photon flux density: $26^{\circ} \mathrm{C}$ and $40 \mu \mathrm{mol}$ photons $\mathrm{m}^{-2} \cdot \mathrm{s}^{-1} ; 26^{\circ} \mathrm{C}$ and 110 umol photons $\cdot \mathrm{m}^{-2} \cdot \mathrm{s}^{-1} ; 15^{\circ} \mathrm{C}$ and $40 \mu \mathrm{mol}$ photons $\cdot \mathrm{m}^{-2} \cdot \mathrm{s}^{-1} ; \quad 15^{\circ} \mathrm{C}$ and $110 \mu \mathrm{mol}$ photons $\cdot \mathrm{m}^{-2} \cdot \mathrm{s}^{-1}$. All experiments were initiated by the inoculation of each flask with exponentially growing cells (acclimated to the experimental conditions for 30 days) at a density of $5.0 \times 10^{3}$ cells $\mathrm{ml}^{-1}$. Three replicates of each treatment were established.

TABLE I

Strains of Dunaliella salina included in this study

\begin{tabular}{|c|c|c|}
\hline Strain & Geographic origin & Source $^{1}$ \\
\hline D. salina $\mathrm{CONC}-001$ & La Rinconada Lagoon, Antofagasta, Chile & CONC-001 \\
\hline D. salina $\mathrm{CONC}-006$ & Sector Burro Muerto, Salar de Atacama, Chile & CONC-006 \\
\hline D. salina $\mathrm{CONC}-007$ & Sector Puilar, Salar de Atacama, Chile & CONC-007 \\
\hline D. salina Mexican & Yucatán, Mexico & $\begin{array}{l}\text { Provided by Ernesto Retamales, } \\
\text { U. Antofagasta, Chile }\end{array}$ \\
\hline D. salina Chinese & Tanggu, China & $\begin{array}{l}\text { Provided by Dr. Ralph Lewin, } \\
\text { Scripps Institution, USA }\end{array}$ \\
\hline D. salina Australian & Hutt Lagoon, Australia & CCAP-19/18 \\
\hline D. bardawil & Bardawil Lake, Israel/Egypt & ATCC-30861 \\
\hline
\end{tabular}

CONC: Culture Collection of Microalgae, Universidad de Concepción, Concepción, Chile.

CCAP: Culture Collection of Algae and Protozoa, United Kingdom.

ATCC: American Type Culture Collection, VA, USA.

${ }^{1}$ All the strains are currently available in CONC. 


\section{Growth parameters}

Growth was monitored over a 30-day period by cell counts of the replicate whose $\mathrm{A}_{750 \mathrm{~nm}}$ was the nearest to the replicates' treatment average. Cell counts were performed every four days in $1 \mathrm{ml}$ Utermöhl counting chambers. The growth rate, $\mathrm{k}$ (divisions $\mathrm{day}^{-1}$ ) was evaluated during the logarithmic growth phase as in Cifuentes and colleagues (1996a).

\section{Pigments analysis}

Total carotenoids, chlorophylls $a$ and $b, \alpha-$ carotene, and 9-cis and all-trans $\beta$-carotene were estimated at an early stationary phase: in 25 day-old cultures for the treatments at $26^{\circ} \mathrm{C}$ and in 33 day-old cultures for the treatments at $15^{\circ} \mathrm{C}$. The total carotenoids and chlorophyll content were determined spectrophotometrically from algal pellets using a $90 \%(\mathrm{v} / \mathrm{v})$ acetone/water mixture (Wegmann \& Metzner 1971). Carotenoid composition was analyzed in dichloromethane extracts by HPLC using a chromatograph LDC Analytical with UVVisible detector. A stainless steel column of $25 \mathrm{~cm} \times 4 \mathrm{~mm}$ i.d. packed with $\mathrm{C} 18$ reversed phase material of $5 \mu \mathrm{m}$ particle size was used. Elution was performed with

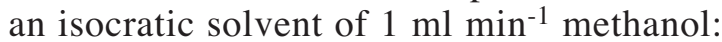
dichloromethane 90: $10 \mathrm{v} / \mathrm{v}$, and a $450 \mathrm{~nm}$ wavelength was utilized for detection. All solvents were filtered and degassed prior to use. Pigment identification was performed using synthetic $\beta$-carotene (Merck, Germany) as a standard (100\% all-trans isomer) and the elution order reported for these pigments in similar chromatographic systems (Ben-Amotz et al., 1988). The relative content of each carotene $(\alpha-$ carotene, 9-cis $\beta$-carotene and all-trans $\beta$ carotene) was determined by estimation of each peak's area with respect to the sum of all their areas.

\section{Statistical analysis}

Carotenogenesis parameters were analyzed by three-way analysis of variance (ANOVA) with the factors: strain, irradiance and temperature as independent variables. For multiple comparisons, tests of Tukey and Scheffe were used. Differences were considered to be significant at a probability of $5 \%$ ( $\mathrm{P} \leq$ $0.05)$. The computational program used was STATISTICA version 6.0.

\section{RESULTS}

\section{Growth}

Under all the culture conditions, the nonChilean strains and the strain CONC-001 showed the highest growth rates and maximum cell densities, whereas the strains CONC-006 and CONC-007 exhibited the lowest values in both parameters (Fig. 1, Table II).

Independent of the photon flux density, all the strains reached higher growth rates at the highest assayed temperature $\left(26^{\circ} \mathrm{C}\right)$. However, the strains from Mexico, China and Australia showed a slight decrease of growth rate at the highest photon flux density (Fig. 1, Table II).

In cultures maintained at the same photon flux density, the higher temperature increased the carrying capacity in most of the strains. Nevertheless, the strains from Mexico, China and CONC-006 from Chile exhibited, in some conditions, equal or lower maximum cell density at $26^{\circ} \mathrm{C}$ than at $15^{\circ} \mathrm{C}$ (Table II).

\section{Total carotenoids}

The three-way ANOVA revealed that strain identity was the most significant source of variation in total carotenoids accumulation (expressed as carotenoids per volume, carotenoids per cell and carotenoids/ chlorophyll a ratio). Moreover, and even though the temperature effect alone was more significant than the irradiance effect in determining these responses, a significant interaction between both parameters was detected.

The Australian strain and the strain CONC-007 were the most carotenogenic under all culture conditions. The Australian strain exhibited the maximum carotenoid accumulation per culture volume unit (40.7 
$\pm 1.0 \mathrm{mg} \cdot \mathrm{L}^{-1}$ at $15^{\circ} \mathrm{C}$ and $110 \mu \mathrm{mol}$ photons $\cdot \mathrm{m}^{-2} \cdot \mathrm{s}^{-1}$ ), while CONC-007 showed the maximum amount of carotenoids per cell $\left(92.4 \pm 4.7 \mathrm{pg} \cdot\right.$ cell $^{-1}$ at $26^{\circ} \mathrm{C}$ and 40 umol photons $\cdot \mathrm{m}^{-2} \cdot \mathrm{s}^{-1}$ ) (Table III). Even though $D$. bardawil showed a carotenogenic capacity similar to that of CONC-007 in terms of carotenoids per culture volume unit, D. bardawil had a four- to six-fold lower accumulating capacity in carotenoids per cell than CONC-007 (Table III).

CONC-006 was the only strain that showed a statistically significant tendency $(\mathrm{p}<0.05)$ for higher carotenoid accumulation per cell at the highest irradiance $\left(110 \mu \mathrm{mol}\right.$ photons $\left.\cdot \mathrm{m}^{-2} \cdot \mathrm{s}^{-1}\right)$ at either temperature. At $26^{\circ} \mathrm{C}$, the Chinese and Australian strains as well as CONC-007 accumulated more carotenoids per cell at the lowest irradiance (Table III). The same tendency was exhibited by the last two strains in terms of carotenoids per culture volume (Table III).

The strain CONC-007 had the highest carotenoid/chlorophyll ratio in all the assayed culture conditions. At $110 \mu \mathrm{mol}$ photons $\cdot \mathrm{m}^{-2} \cdot \mathrm{s}^{-1}$, the carotenoid/chlorophyll ratio was significantly higher $(\mathrm{p}<0.05)$ for all the strains at the lowest temperature (Table III). At the highest temperature, all strains except for CONC-006 exhibited higher carotenoid/chlorophyll ratio at 40 rather than at $110 \mu \mathrm{mol}$ photons $\cdot \mathrm{m}^{-2} \cdot \mathrm{s}^{-1}$ (Table III).
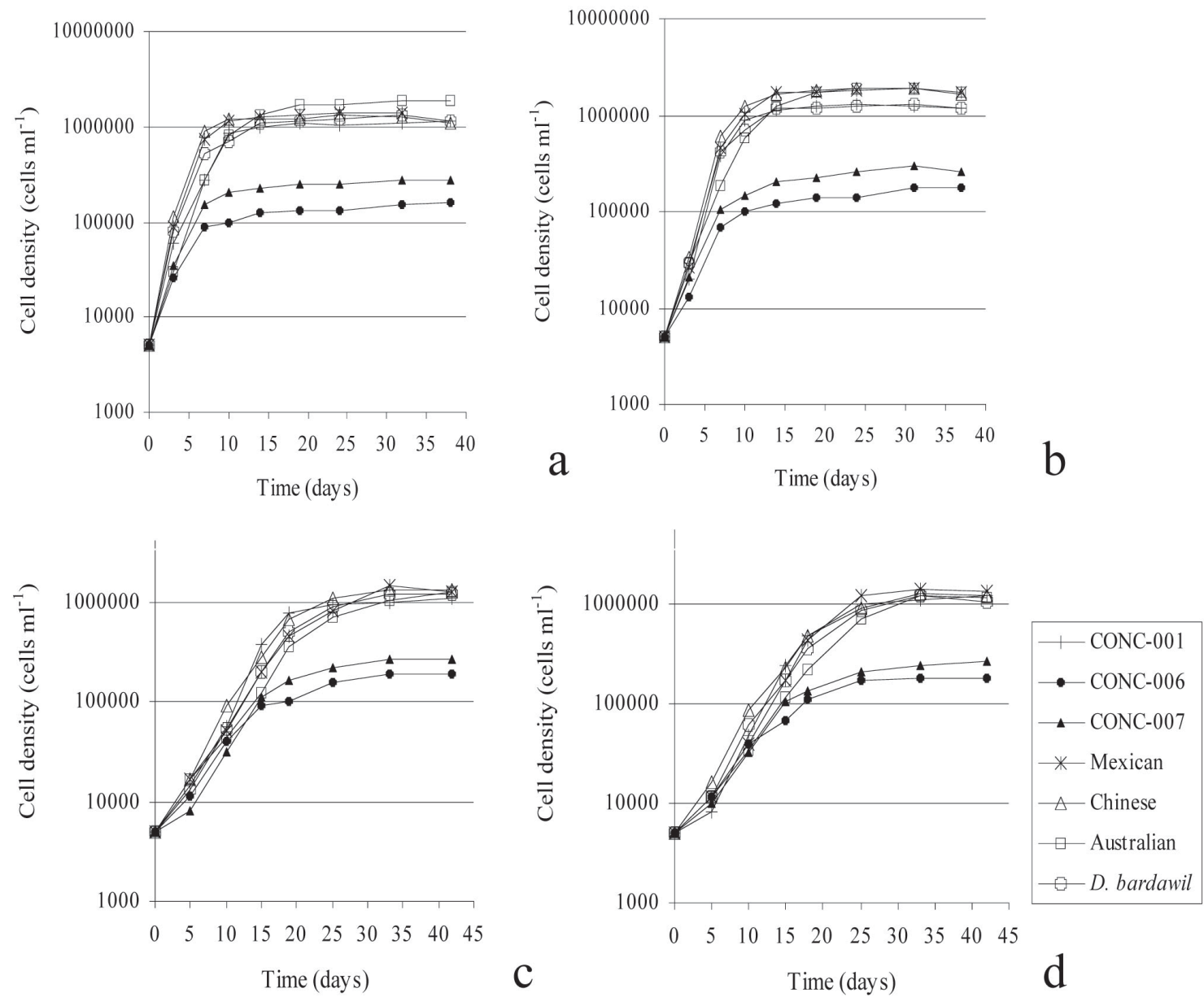

Fig. 1. Comparison of growth of three Chilean and four non-Chilean strains of D. salina in cultures maintained under four different treatment combinations of temperature and irradiance: a: $26^{\circ} \mathrm{C}$ and $40 \mu \mathrm{mol}$ photons $\cdot \mathrm{m}^{-2} \cdot \mathrm{s}^{-1}$; b: $26^{\circ} \mathrm{C}$ and $110 \mu \mathrm{mol}$ photons $\cdot \mathrm{m}^{-2} \cdot \mathrm{s}^{-1}$; $\mathrm{c}: 15^{\circ} \mathrm{C}$ and $40 \mu \mathrm{mol}$ photons $\mathrm{m}^{-2} \cdot \mathrm{s}^{-1}$ and $\mathrm{d}: 15^{\circ} \mathrm{C}$ and $110 \mu \mathrm{mol}$ photons $\mathrm{m}^{-2} \cdot \mathrm{s}^{-1}$. 
TABLE II

Division rate $(\mathrm{k})$ and maximum cell density $\left(\mathrm{N}_{\max }\right)$ reached by the seven strains of $D$. salina in each culture condition

\begin{tabular}{|c|c|c|c|c|c|c|c|c|}
\hline \multirow[t]{2}{*}{ Strain } & \multicolumn{2}{|c|}{$\begin{array}{l}26^{\circ} \mathrm{C} \text { and } 40 \mu \mathrm{mol} \\
\text { photons } \cdot \mathrm{m}^{-2} \cdot \mathrm{s}^{-1}\end{array}$} & \multicolumn{2}{|c|}{$\begin{array}{c}26^{\circ} \mathrm{C} \text { and } 110 \mu \mathrm{mol} \\
\text { photons } \cdot \mathrm{m}^{-2} \cdot \mathrm{s}^{-1}\end{array}$} & \multicolumn{2}{|c|}{$\begin{array}{l}15^{\circ} \mathrm{C} \text { and } 40 \mu \mathrm{mol} \\
\text { photons } \cdot \mathrm{m}^{-2} \cdot \mathrm{s}^{-1}\end{array}$} & \multicolumn{2}{|c|}{$\begin{array}{c}15^{\circ} \mathrm{C} \text { and } 110 \mu \mathrm{mol} \\
\text { photons } \cdot \mathrm{m}^{-2} \cdot \mathrm{s}^{-1}\end{array}$} \\
\hline & $\begin{array}{c}\mathrm{k} \\
\left(\operatorname{div} \mathrm{day}^{-1}\right)\end{array}$ & $\begin{array}{c}\mathrm{N}_{\max } \\
\text { (cells ml-1) }\end{array}$ & $\begin{array}{c}\mathrm{k} \\
\left(\operatorname{div} \mathrm{day}^{-1}\right)\end{array}$ & $\begin{array}{c}\mathrm{N}_{\max } \\
\text { (cells ml-1) }\end{array}$ & $\begin{array}{c}\mathrm{k} \\
\left(\operatorname{div} \mathrm{day}^{-1}\right)\end{array}$ & $\begin{array}{c}\mathrm{N}_{\max } \\
\text { (cells } \mathrm{ml}^{-1} \text { ) }\end{array}$ & $\begin{array}{c}\mathrm{k} \\
\left(\operatorname{div} \mathrm{day}^{-1}\right)\end{array}$ & $\begin{array}{c}\mathrm{N}_{\max } \\
\text { (cells } \mathrm{ml}^{-1} \text { ) }\end{array}$ \\
\hline CONC-001 & 0.9 & $1.2 \times 10^{6}$ & 0.9 & $1.3 \times 10^{6}$ & 0.4 & $1.1 \times 10^{6}$ & 0.4 & $1.2 \times 10^{6}$ \\
\hline CONC-006 & 0.6 & $1.6 \times 10^{5}$ & 0.6 & $1.8 \times 10^{5}$ & 0.2 & $1.9 \times 10^{5}$ & 0.2 & $1.8 \times 10^{5}$ \\
\hline CONC-007 & 0.7 & $2.7 \times 10^{5}$ & 0.7 & $2.9 \times 10^{5}$ & 0.3 & $2.6 \times 10^{5}$ & 0.3 & $2.7 \times 10^{5}$ \\
\hline Mexican & 1.1 & $1.4 \times 10^{6}$ & 0.9 & $1.9 \times 10^{6}$ & 0.3 & $1.4 \times 10^{6}$ & 0.4 & $1.4 \times 10^{6}$ \\
\hline Chinese & 1.2 & $1.3 \times 10^{6}$ & 1.0 & $1.9 \times 10^{6}$ & 0.4 & $1.3 \times 10^{6}$ & 0.4 & $1.3 \times 10^{6}$ \\
\hline Australian & 0.9 & $1.9 \times 10^{6}$ & 0.8 & $1.9 \times 10^{6}$ & 0.3 & $1.3 \times 10^{6}$ & 0.3 & $1.2 \times 10^{6}$ \\
\hline D.bardawil & 1.0 & $1.3 \times 10^{6}$ & 1.0 & $1.3 \times 10^{6}$ & 0.3 & $1.2 \times 10^{6}$ & 0.3 & $1.2 \times 10^{6}$ \\
\hline
\end{tabular}

\section{TABLE III}

Chlorophyll $a(\mathrm{Chl} a)$ and $b(\mathrm{Chl} b)$, total carotenoid content (Car) per volume $\left(\mathrm{mg} \cdot \mathrm{L}^{-1}\right)$ and per cell (pg-cell $\left.{ }^{-1}\right), \mathrm{Car} / \mathrm{Chl} a$, relative content of $\alpha$ and $\beta$-carotene $(\alpha$-car $\% ; \beta$-car $\%)$, and 9-cis/all-trans $\beta$-carotene ratio (given as mean value \pm standard deviation) in different strains of $D$. salina (estimated at stationary phase of growth), grown at the following conditions of temperature and irradiance: a) $26^{\circ} \mathrm{C} / 40 \mu \mathrm{mol}$ photons $\cdot \mathrm{m}^{-2} \cdot \mathrm{s}^{-1}$; b) $26^{\circ} \mathrm{C} / 110$ $\mu \mathrm{mol}$ photons $\cdot \mathrm{m}^{-2} \cdot \mathrm{s}^{-1}$; c) $15^{\circ} \mathrm{C} / 40 \mu \mathrm{mol}$ photons $\cdot \mathrm{m}^{-2} \cdot \mathrm{s}^{-1}$; d) $15^{\circ} \mathrm{C} / 110 \mu \mathrm{mol}$ photons $\cdot \mathrm{m}^{-2} \cdot \mathrm{s}^{-1}$.

a) $26^{\circ} \mathrm{C} / 40 \mu \mathrm{mol}$ photons $\cdot \mathrm{m}^{-2} \cdot \mathrm{s}^{-1}$

\begin{tabular}{|c|c|c|c|c|c|c|c|c|}
\hline Strain & $\begin{array}{c}\text { Chl } a \\
\left(\mu g \cdot L^{-1}\right)\end{array}$ & $\begin{array}{c}\text { Chl } b \\
\left(\mu g \cdot L^{-1}\right)\end{array}$ & $\begin{array}{c}\text { Car } \\
\left(\mu g \cdot L^{-1}\right)\end{array}$ & Car/Chl $a$ & $\begin{array}{c}\text { Car } \\
\left(\mathrm{pg} \cdot \operatorname{cell}^{-1}\right)\end{array}$ & $\alpha-\operatorname{car}(\%)$ & $\beta-\operatorname{car}(\%)$ & $\begin{array}{l}\text { 9-cis/all- } \\
\text { trans } \beta \text { car }\end{array}$ \\
\hline CONC-001 & $950 \pm 26$ & $240 \pm 30$ & $7979 \pm 511$ & $8.4 \pm 0.5$ & $8.4 \pm 0.5$ & $17.3 \pm 2.8$ & $82.7 \pm 2.8$ & $1.1 \pm 0.1$ \\
\hline CONC-006 & $464 \pm 50$ & $181 \pm 20$ & $4560 \pm 290$ & $9.9 \pm 0.7$ & $35.7 \pm 2.3$ & $27.3 \pm 2.6$ & $72.7 \pm 2.6$ & $2.2 \pm 0.05$ \\
\hline CONC-007 & $935 \pm 79$ & $568 \pm 96$ & $26248 \pm 1337$ & $28.2 \pm 3.1$ & $92.4 \pm 4.7$ & $21.3 \pm 1.4$ & $78.7 \pm 1.4$ & $2.3 \pm 0.4$ \\
\hline Mexican & $1328 \pm 56$ & $502 \pm 59$ & $21894 \pm 416$ & $16.5 \pm 0.4$ & $14.4 \pm 0.2$ & ND & $100 \pm 0.0$ & $1.9 \pm 0.1$ \\
\hline Chinese & $1441 \pm 148$ & $572 \pm 28$ & $17889 \pm 819$ & $12.5 \pm 1.7$ & $15.0 \pm 0.7$ & ND & $100 \pm 0.0$ & $2.1 \pm 0.1$ \\
\hline Australian & $1902 \pm 83$ & $447 \pm 25$ & $38683 \pm 2442$ & $20.4 \pm 1.7$ & $19.6 \pm 1.2$ & ND & $100 \pm 0.0$ & $1.5 \pm 0.05$ \\
\hline D.bardawil & $2389 \pm 136$ & $667 \pm 26$ & $16536 \pm 418$ & $6.9 \pm 0.5$ & $14.3 \pm 0.4$ & ND & $100 \pm 0.0$ & $2.2 \pm 0.2$ \\
\hline
\end{tabular}


Table III. Cont.

b) $26^{\circ} \mathrm{C} / 110 \mu \mathrm{mol}$ photons $\cdot \mathrm{m}^{-2} \cdot \mathrm{s}^{-1}$

\begin{tabular}{lcccccccc}
\hline Strain & $\begin{array}{c}\mathrm{Chl} a \\
\left(\mu \mathrm{g} \cdot \mathrm{L}^{-1}\right)\end{array}$ & $\begin{array}{c}\mathrm{Chl} b \\
\left(\mu \mathrm{g} \cdot \mathrm{L}^{-1}\right)\end{array}$ & $\begin{array}{c}\mathrm{Car} \\
\left(\mu \mathrm{g} \cdot \mathrm{L}^{-1}\right)\end{array}$ & $\begin{array}{c}\mathrm{Car} / \mathrm{Chl} a \\
\left(\mathrm{pg} \cdot \mathrm{cell} l^{-1}\right)\end{array}$ & $\alpha$-car $(\%)$ & $\beta$-car $(\%)$ & $\begin{array}{c}\text { 9-cis/all- } \\
\text { trans } \beta \text { car }\end{array}$ \\
\hline CONC-001 & $1338 \pm 32$ & $473 \pm 32$ & $10292 \pm 298$ & $7.7 \pm 0.2$ & $9.0 \pm 0.3$ & $17.4 \pm 0.4$ & $82.6 \pm 0.4$ & $1.1 \pm 0.0$ \\
CONC-006 & $431 \pm 12$ & $250 \pm 19$ & $5421 \pm 48$ & $12.6 \pm 0.2$ & $44.3 \pm 0.4$ & $30.6 \pm 1.7$ & $69.4 \pm 1.7$ & $1.8 \pm 0.2$ \\
CONC-007 & $694 \pm 15$ & $375 \pm 58$ & $16000 \pm 952$ & $23.2 \pm 1.0$ & $72.1 \pm 1.1$ & $24.5 \pm 0.8$ & $75.5 \pm 0.8$ & $2.1 \pm 0.0$ \\
Mexican & $1935 \pm 29$ & $672 \pm 10$ & $22765 \pm 477$ & $11.8 \pm 0.1$ & $17.7 \pm 0.3$ & $\mathrm{ND}$ & $100 \pm 0.0$ & $1.9 \pm 0.3$ \\
Chinese & $1585 \pm 63$ & $544 \pm 11$ & $21092 \pm 402$ & $13.3 \pm 0.2$ & $11.2 \pm 0.2$ & $\mathrm{ND}$ & $100 \pm 0.0$ & $1.8 \pm 0.1$ \\
Australian & $1807 \pm 13$ & $530 \pm 5$ & $24580 \pm 19$ & $13.6 \pm 0.1$ & $13.2 \pm 0.1$ & $\mathrm{ND}$ & $100 \pm 0.0$ & $1.4 \pm 0.1$ \\
D.bardawil & $2702 \pm 88$ & $924 \pm 11$ & $20504 \pm 526$ & $7.6 \pm 0.05$ & $16.9 \pm 0.4$ & $\mathrm{ND}$ & $100 \pm 0.0$ & $2.1 \pm 0.2$ \\
\hline
\end{tabular}

c) $15^{\circ} \mathrm{C} / 40 \mu \mathrm{mol}$ photons $\cdot \mathrm{m}^{-2} \cdot \mathrm{s}^{-1}$

\begin{tabular}{|c|c|c|c|c|c|c|c|c|}
\hline Strain & $\begin{array}{c}\text { Chl } a \\
\left(\mu \mathrm{g} \cdot \mathrm{L}^{-1}\right)\end{array}$ & $\begin{array}{c}\text { Chl } b \\
\left(\mu \mathrm{g} \cdot \mathrm{L}^{-1}\right)\end{array}$ & $\begin{array}{c}\text { Car } \\
\left(\mu \mathrm{g} \cdot \mathrm{L}^{-1}\right)\end{array}$ & Car/Chl $a$ & $\begin{array}{c}\text { Car } \\
\left(\mathrm{pg} \cdot \text { cell }^{-1}\right)\end{array}$ & $\alpha-\operatorname{car}(\%)$ & $\beta-\operatorname{car}(\%)$ & $\begin{array}{l}\text { 9-cis/all- } \\
\text { trans } \beta \text { car }\end{array}$ \\
\hline CONC-001 & $1011 \pm 14$ & $362 \pm 36$ & $8784 \pm 16$ & $8.7 \pm 0.2$ & $8.8 \pm 0.3$ & $34.6 \pm 2.0$ & $65.4 \pm 2.0$ & $1.3 \pm 0.2$ \\
\hline CONC-006 & $458 \pm 29$ & $262 \pm 35$ & $8939 \pm 49$ & $19.6 \pm 1.2$ & $46.8 \pm 2.3$ & $33.7 \pm 1.8$ & $66.3 \pm 1.8$ & $2.1 \pm 0.06$ \\
\hline CONC-007 & $626 \pm 7$ & $696 \pm 16$ & $20921 \pm 134$ & $33.4 \pm 0.6$ & $79.8 \pm 1.0$ & $37.0 \pm 2.6$ & $63.0 \pm 2.6$ & $2.1 \pm 0.2$ \\
\hline Mexican & $1708 \pm 17$ & $649 \pm 22$ & $25589 \pm 892$ & $15.0 \pm 0.5$ & $17.8 \pm 0.6$ & $11.8 \pm 0.6$ & $88.2 \pm 0.6$ & $1.8 \pm 0.1$ \\
\hline Chinese & $1716 \pm 21$ & $774 \pm 12$ & $29013 \pm 446$ & $16.9 \pm 0.2$ & $22.5 \pm 0.3$ & $11.4 \pm 0.8$ & $88.6 \pm 0.8$ & $2.4 \pm 0.2$ \\
\hline Australian & $1833 \pm 30$ & $822 \pm 19$ & $35851 \pm 255$ & $19.5 \pm 0.2$ & $34.3 \pm 1.0$ & $8.0 \pm 0.4$ & $92.0 \pm 0.4$ & $2.0 \pm 0.1$ \\
\hline D.bardawil & $1967 \pm 24$ & $809 \pm 7$ & $24453 \pm 636$ & $12.4 \pm 0.2$ & $21.1 \pm 0.5$ & $11.6 \pm 0.4$ & $88.4 \pm 1.9$ & $2.3 \pm 0.1$ \\
\hline
\end{tabular}

d) $15^{\circ} \mathrm{C} / 110 \mu \mathrm{mol}$ photons $\cdot \mathrm{m}^{-2} \cdot \mathrm{s}^{-1}$

\begin{tabular}{lcccccccc}
\hline Strain & $\begin{array}{c}\mathrm{Chl} a \\
\left(\mu \mathrm{g} \cdot \mathrm{L}^{-1}\right)\end{array}$ & $\begin{array}{c}\mathrm{Chl} b \\
\left(\mu \mathrm{g} \cdot \mathrm{L}^{-1}\right)\end{array}$ & $\begin{array}{c}\mathrm{Car} \\
\left(\mu \mathrm{g} \cdot \mathrm{L}^{-1}\right)\end{array}$ & $\left.\begin{array}{c}\mathrm{Car} / \mathrm{Chl} a \\
(\mathrm{pg} \cdot \mathrm{cell}\end{array} \mathbf{1}^{-1}\right)$ & $\alpha$-car $(\%)$ & $\beta$-car $(\%)$ & $\begin{array}{c}\text { 9-cis/all- } \\
\text { trans } \beta \text { car }\end{array}$ \\
\hline CONC-001 & $1207 \pm 100$ & $452 \pm 54$ & $12355 \pm 306$ & $10.3 \pm 0.6$ & $11.1 \pm 0.3$ & $32.7 \pm 0.4$ & $67.3 \pm 0.4$ & $1.2 \pm 0.06$ \\
CONC-006 & $494 \pm 24$ & $276 \pm 23$ & $10010 \pm 32$ & $20.3 \pm 1.0$ & $61.1 \pm 1.6$ & $36.3 \pm 0.4$ & $63.7 \pm 0.4$ & $2.0 \pm 0.1$ \\
CONC-007 & $644 \pm 48$ & $326 \pm 12$ & $21789 \pm 207$ & $33.9 \pm 2.8$ & $90.7 \pm 0.8$ & $39.9 \pm 1.6$ & $60.1 \pm 1.6$ & $2.2 \pm 0.1$ \\
Mexican & $1924 \pm 34$ & $1144 \pm 137$ & $31857 \pm 1016$ & $16.6 \pm 0.5$ & $18.7 \pm 0.6$ & $12.9 \pm 1.0$ & $87.1 \pm 1.0$ & $1.8 \pm 0.2$ \\
Chinese & $1547 \pm 45$ & $832 \pm 31$ & $27315 \pm 1263$ & $17.7 \pm 0.3$ & $21.7 \pm 1.0$ & $11.6 \pm 1.0$ & $88.4 \pm 1.0$ & $2.0 \pm 0.06$ \\
Australian & $1729 \pm 24$ & $599 \pm 7$ & $40665 \pm 1051$ & $23.3 \pm 1.2$ & $33.9 \pm 1.3$ & $10.4 \pm 0.2$ & $89.6 \pm 0.2$ & $1.2 \pm 0.1$ \\
D.bardawil & $1660 \pm 38$ & $689 \pm 49$ & $25812 \pm 754$ & $15.5 \pm 0.4$ & $21.2 \pm 0.4$ & $13.0 \pm 1.0$ & $87.0 \pm 1.0$ & $1.9 \pm 0.1$ \\
\hline
\end{tabular}




\section{Relative composition of carotenes}

Temperature was the principal determining factor in $\alpha$ - and $\beta$-carotene accumulation in the strains, whereas irradiance was the most important determining factor in the 9-cis/all-trans $\beta$-carotene ratio, as indicated by the three-way ANOVA. Temperature and irradiance did not interact: while $15^{\circ} \mathrm{C}$ was the optimal temperature for the $\alpha$-carotene accumulation, $26^{\circ} \mathrm{C}$ was best for $\beta$ carotene accumulation, and 40 umol photons $\cdot \mathrm{m}^{-2} \cdot \mathrm{s}^{-1}$ the most favorable photon flux density for a maximum 9-cis/all-trans $\beta$-carotene ratio.

The Chilean strains of $D$. salina accumulated $\alpha$-carotene (15\% to $40 \%$ ) at both assayed temperatures, while the nonChilean strains accumulated it in detectable amounts $(<15 \%)$ only during growth at $15^{\circ} \mathrm{C}$ (Table III). Moreover, low temperature favored $\alpha$-carotene production in the Chilean strains, this response being especially remarkable for CONC-001 and CONC-007 (Table III).

In general, irradiance did not affect the $\alpha$-carotene production in the strains analyzed, except for the Australian strain, which accumulated a higher proportion of this pigment at $110 \mu \mathrm{mol}$ photons $\cdot \mathrm{m}^{-2} \cdot \mathrm{s}^{-1}$.

The relative content of $\beta$-carotene in all the strains was higher at $26^{\circ} \mathrm{C}$ than at $15^{\circ} \mathrm{C}$ (Table III). The accumulation of this pigment by the cells was independent of the photon flux density, except for the Australian strain, which showed a significantly higher $(p<0.05)$ accumulation of this pigment at $40 \mu \mathrm{mol} \mathrm{m} \mathrm{m}^{-2} \mathrm{~s}^{-1}$ for growth at $15^{\circ} \mathrm{C}$ (Table III).

All of the strains under any culture conditions exhibited 9-cis/all-trans $\beta$ carotene ratios higher than 1.0. In general, the highest values in this parameter were obtained at the lowest photon flux density. These values were significantly higher in the strain $\mathrm{CONC}-006$ at $26^{\circ} \mathrm{C}$, in the Australian strain at $15^{\circ} \mathrm{C}$ and in the Chinese strain at both temperatures. The maximum value of 2.4 was obtained by the Chinese strain for growth at $15^{\circ} \mathrm{C}$ and 40 umolm ${ }^{-2} \mathrm{~s}^{-1}$ (Table III).

\section{DISCUSSION}

Dunaliella salina is a photosynthetic organism with a unique ecophysiological adaptive capacity, as has been shown by the wide range of physiological responses to different culture conditions, exhibited by the seven strains studied. These strains have been genetically characterized using random amplified polymorphic DNA (RAPD) band patterns and nuclear ribosomal DNA internal transcribed spacer (ITS-1 and ITS-2) sequences (Gómez \& González, 2004). The physiological attributes revealed by the strains in this study are mostly in agreement with the genetic relationships found among them, which demonstrates the genome participation in the determination of the intraspecific physiological differences detected here.

Considering that in its natural environment the optimal growth temperatures for $D$. salina are higher than $21^{\circ} \mathrm{C}$ (Borowitzka, 1981), it is not surprising that all the strains exhibited greater growth rates at $26^{\circ} \mathrm{C}$ than at $15^{\circ} \mathrm{C}$ (Fig. 1, Table II). Furthermore, the carrying capacity of most of the cultures was also positively affected by high temperature (Table II).

The coastal strain CONC-001 from Chile exhibited growth rates and growth curves very similar to the four non-Chilean strains (Mexican, Chinese, Australian and $D$. bardawil), which also all come from coastal hypersaline environments. In contrast, the strains (CONC-006 and CONC-007) from the Salar de Atacama (alpine hypersaline environment) exhibited lower growth rates than all of the other strains, and these two Chilean strains attained the lowest cell densities in all culture conditions (Fig. 1, Table II). On the other hand, the carotenoids content per cell was significantly higher in the strains from the Salar de Atacama under the assayed culture conditions (Table III).

Previous studies have already reported low carrying capacities accompanied by unusually high carotenoids per cell accumulation in strains CONC-006 and CONC-007 grown under very different 
culture conditions (Cifuentes et al., 1992). The persisting physiological behavior of these strains might be explained as a physiological adaptation to the prevalent conditions in the habitat for which their genotypes were selected. The Salar de Atacama is a hypersaline environment of $3,000 \mathrm{~km}^{2}$ located at an altitude of 2,340 meters in the Atacama Desert. Some of the abiotic characteristics of this salt lake are cloudless skies almost all year round and very high solar radiation (Parra et al., 1990; Alonso \& Risacher, 1996; Risacher \& Alonso, 1996). In this type of aquatic environment, $\mathrm{O}_{2}$ and $\mathrm{CO}_{2}$ solubility are strongly reduced due to altitude, salinity and high temperature (Borowitzka, 1981; Borowitzka \& Borowitzka, 1988), which could explain the low carrying capacities exhibited by these strains. On the other hand, the high free radical production in a highly irradiated environment like the Salar de Atacama could explain the high carotenoid per cell accumulation shown by these strains.

Except for the extensive studies on carotenogenesis already done on $D$. bardawil from a physiological (e.g., BenAmotz \& Avron, 1983a; Ben-Amotz et al.1988; Ben-Amotz, 1996) and a molecular point of view (Lers et al., 1990; 1991; Levy et al., 1993), there is no published information on the carotenogenic capacity and/or the growing characteristics of most of the non-Chilean strains of $D$. salina studied in this paper. There are no previous studies on the Mexican strain, whereas the existing information for the Chinese and Australian strains is unavailable due to the commercial utilization of these strains.

According to this study's results, the strain was the main factor controlling total carotenoid accumulation and carotenoids/ chlorophyll ratio. The most carotenogenic strain, expressed as carotenoids per cell, was the Chilean strain CONC-007; while when expressed as carotenoids per volume of culture, the Australian strain was the most carotenogenic (Table III). From a commercial point of view, a strain with high carotenoids per cell yield is tremendously profitable, since its culture should produce a much purer final product.
In carotenoids/chlorophyll ratio - another final product purity parameter - the strain CONC-007 was, definitively, the best (see Table III). Therefore, in spite of the fact that the strain CONC-007 produces less carotenoids per volume than the Australian strain, it is better for commercial applications since its algal power is much richer in carotenoids.

\section{Ben-Amotz and Avron (1983a)} demonstrated that the $\beta$-carotene/ chlorophyll ratio in $D$. bardawil increases as a function of the integral amount of light that the alga receives during a division cycle (irradiance $x$ doubling time). Therefore, an increase of the doubling time, by a decrease of temperature at the same irradiance, should increase the $\beta$-carotene/ chlorophyll ratio, as occurred in this study. Even though this tendency was reported for exponentially growing cells, our results show that it is also true during the stationary growth phase as a higher carotenoids/chlorophyll ratio demonstrates, at least at $110 \mu \mathrm{mol}$ photons $\cdot \mathrm{m}^{-2} \cdot \mathrm{s}^{-1}$, for all strains at the lower culture temperature (Table III).

Ben-Amotz and colleagues (1988) found that the 9 -cis/all-trans $\beta$-carotene ratio increased from 0.21 to 1.3 in $D$. bardawil when the photon flux density increased from 50 to $2000 \mu \mathrm{mol}$ photons $\cdot \mathrm{m}^{-2} \cdot \mathrm{s}^{-1}$. However, Jiménez and Pick (1994) and Orset and Young (2000), revealed that 9-cis $\beta$-carotene synthesis is promoted by low (20 to $50 \mu \mathrm{mol}$ photons $\left.\cdot \mathrm{m}^{-2} \cdot \mathrm{s}^{-1}\right)$, rather than high (200 to $1250 \mu \mathrm{mol}$ photons $\mathrm{m}^{-2} \cdot \mathrm{s}^{-1}$ ) irradiances in the same strain. Even though the irradiance range used in this study was much narrower (40 to $110 \mu \mathrm{mol}$ photons $\mathrm{m}^{-2} \cdot \mathrm{s}^{-1}$ ) than that used by the previous authors, we almost always found a higher proportion of 9-cis over the all-trans isomer at the lower irradiance for the same culture temperature (Table III).

Under any culture condition, the Chilean strain CONC-007 exhibited a higher 9-cis/all-trans $\beta$-carotene ratio than the Australian strain (Table III), which is another commercially advantageous attribute.

In its natural environment, when $D$. salina is exposed to extremely high 
irradiances the $\beta$-carotene accumulated at the interthylakoidal globules prevents its photo-oxidative cell damage (Ben-Amotz et al., 1982; 1989). Ben-Amotz (1996) analyzed the temperature effect in the $\beta$ carotene isomers composition of $D$. bardawil globules, finding that if the culture temperature decreases from $30^{\circ} \mathrm{C}$ to $10^{\circ} \mathrm{C}$, the 9 -cis/all-trans $\beta$-carotene ratio increases four-fold. In the present study, a temperature decrease from $26^{\circ} \mathrm{C}$ to $15^{\circ} \mathrm{C}$ did not significantly affect the 9-cis/alltrans $\beta$-carotene ratio in $D$. bardawil at any photon flux density (Table III). In contrast to Ben-Amotz (1996), we determined pigment composition in the total algal extract, which includes $\beta$ carotene from the interthylakoid globules as well as that from the thylakoid lightabsorbing antennas. In this context, Jiménez and Pick (1994) pointed out that photosynthetic pool of $\beta$-carotene could make an important contribution to the amount and composition of $D$. salina pigments. They established that both chloroplastic pools of pigments (globules and thylakoids) exhibit different $\beta$ carotene isomer composition and suggested that the globular and thylakoid pool of $\beta$-carotene are distinct in their biosynthesis regulation. In the present study, only the Chinese and Australian strains showed a 9-cis/all-trans $\beta$-carotene ratio significantly higher at $15^{\circ} \mathrm{C}$ than at $26^{\circ} \mathrm{C}$, when cultivated at 40 umol photons $\cdot \mathrm{m}^{-2} \cdot \mathrm{s}^{-1}$ (Table III). These results provide further evidence of the physiological diversity that exists among strains of $D$. salina.

Future studies should elucidate the molecular mechanisms that determine the physiological differences detected among the strains. For example, studies could evaluate if these differences are related with the differential expression of genes related to the biosynthesis and/or accumulation of carotenoids either in globules or in thylakoids.

In 1993, Markovits and colleagues reported the presence of $\alpha$-carotene in two Chilean strains of $D$. salina, which at that time was considered to be an undesirable attribute since no studies existed on the effect that a high consumption of this pigment may have in animal organisms. However, in the past decade a number of papers have described the benefits that various carotenoids, including $\alpha$-carotene, have in cancer prevention (Yuen, 1994; Levy et al., 1995; Challem, 1997; Michaud et al., 2000).

Since the main factor stimulating the synthesis of $\alpha$-carotene in D. salina is the low temperature (Orset \& Young, 1999), it was not surprising that all the non-Chilean strains accumulated $\alpha$-carotene to some extent $(8$ to $13 \%)$ at $15{ }^{\circ} \mathrm{C}$ (Table III). On the other hand, the Chilean strains also accumulated $\alpha$-carotene (17 to $31 \%$ ) at high temperature $\left(26^{\circ} \mathrm{C}\right)$ whereas the nonChilean strains did not (Table III). Low temperature $\left(15^{\circ} \mathrm{C}\right)$ strongly increased $\alpha$ carotene accumulation in Chilean strains, particularly in CONC-007 in which it increased to $40 \%$.

Consequently, the Chilean strain CONC007 appears as the most suitable for commercial purposes due to its desirable traits as a source of natural carotenoids.

Our results show that even though the growth and carotenogenic responses of any strain can be modified by the culture conditions, there is no doubt that they are also a function of the intrinsic attributes of each strain. The recent confirmation of a correlation between the above differences and the genetic polymorphism detected among the studied strains (Gómez \& González, 2004) demonstrate that there exists a genetic basis supporting these physiological differences. However, it will be necessary to establish if these differences can be explained by the differential regulation of gene expression related to the biosynthesis and /or carotenoid accumulation in the two main pools of these pigments in D. salina.

\section{ACKNOWLEDGMENTS}

Supported by FONDECYT N ${ }^{\circ} 2990047$ (to P. Gómez). We thank Dr. Joe Zuccarello (National Herbarium Netherlands) for reading the manuscript and helping us with the English. 


\section{REFERENCES}

ALONSO H, RISACHER F (1996) Geoquímica del Salar de Atacama, parte 1: Origen de los componentes y balance salino. Revista Geológica de Chile 23: 113-122

BECKER EW (1994) Chemical composition. Applications of algae. In: BECKER, EW (ed) Microalgae Biotechnology and Microbiology. London: Cambridge University Press. pp: 177-195, 250-260

BEN-AMOTZ A (1996) Effect of low temperature on the stereoisomer composition of $\beta$-carotene in the halotolerant alga Dunaliella bardawil (Chlorophyta). J Phycol 32: 272-275

BEN-AMOTZ A, AVRON M (1983a) On the factors which determine massive $\beta$-carotene accumulation in the halotolerant alga Dunaliella bardawil. Plant Physiol 72: 593-597

BEN-AMOTZ A, AVRON M (1983b) Accumulation of metabolites by halotolerant algae and its industrial potential. Ann Rev Microbiol 37: 95-119

BEN-AMOTZ A, AVRON M (1989) The biotechnology of mass culturing Dunaliella for products of commercial interest. In: CRESSWELL RC, REES TAV, SHAH N (eds) Algal and Cyanobacterial Biotechnology. New York: Longman Scientific and Technical Press. pp: 91114

BEN-AMOTZ A, AVRON M (1990) The biotechnology of cultivating the halotolerant alga Dunaliella. TIBTECH 8: $121-126$

BEN-AMOTZ A, KATZ A, AVRON M (1982) Accumulation of $\beta$-carotene in halotolerant algae: Purification and characterization of $\beta$-carotene rich globules from Dunaliella bardawil (Chlorophyceae). J Phycol 18: 529-537

BEN-AMOTZ A, LERS A, AVRON M (1988) Stereoisomers of $\beta$-carotene and phytoene in the alga Dunaliella bardawil. Plant Physiol 86: 1286-1291

BEN-AMOTZ A, LEVY Y (1996) Bioavailability of a natural isomer mixture compared with synthetic alltrans $\beta$-carotene in human serum. Am J Clin Nutr 63: 729-734

BEN-AMOTZ A, SHAISH A, AVRON M (1989) Mode of action of the massively accumulated $\beta$-carotene of Dunaliella bardawil in protecting the alga against damage by excess irradiation. Plant Physiol 91: 10401043

BOROWITZKA LJ (1981) The microflora. Adaptations to life in extremely saline lakes. Hydrobiologia 81: 33-46

BOROWITZKA M, BOROWITZKA L (1988) Dunaliella. In: BOROWITZKA M, BOROWITZKA L (eds) Microalgal Biotechnology. London: Cambridge University Press. pp: 27-58, 460-461

BOROWITZKA L, BOROWITZKA M (1989) $\beta$-carotene (provitamin A) production with algae. In: CRESSWELL R, REES T, SHAH N (eds) Algal and Cyanobacterial Biotechnology. New York: Longman Scientific and Technical Press. pp: 15-26

BOROWITZKA M, BOROWITZKA L, MOULTON T (1984) The mass culture of Dunaliella salina for fine chemicals: From laboratory to pilot plant. Hydrobiologia 116/117: 115-121

CHALLEM JJ (1997) Beta-carotene and other carotenoids: Promises, failures, and a new vision. J Orthomolec Med 12: 11-19

CIFUENTES AS, GONZÁLEZ M, CONEJEROS M, DELLAROSSA V, PARRA O (1992) Growth and carotenogenesis in eight strains of Dunaliella salina Teodoresco from Chile. J Appl Phycol 4: 111-118

CIFUENTES AS, GONZÁLEZ M, PARRA O (1996a) The effect of salinity on the growth and carotenogenesis in two Chilean strains of Dunaliella salina Teodoresco. Biol Res 29: 227-236

CIFUENTES AS, GONZÁLEZ M, PARRA O, ZÚÑIGA M (1996b) Cultivo de cepas de Dunaliella salina (Teodoresco 1905) en diferentes medios bajo condiciones de laboratorio. Rev Chilena Hist Nat 69: 105-112

CRAMER DW, KUPER H, HARLOW BL, TITUSERNSTOFF L (2001) Carotenoids, antioxidants and ovarian cancer risk in pre- and postmenopausal women. Int J Cancer 94: 128-134

GÓMEZ P, GONZÁLEZ M (2001) Genetic polymorphism in eight Chilean strains of the carotenogenic microalga Dunaliella salina Teodoresco (Chlorophyta). Biol Res 34: 23-30

GÓMEZ P, BARRIGA A, CIFUENTES AS, GONZÁLEZ M (2003) Effect of salinity on the quantity and quality of carotenoids accumulated by Dunaliella salina (strain CONC-007) and Dunaliella bardawil (strain ATCC 30861) Chlorophyta. Biol Res 36: 185-192

GÓMEZ P, GONZÁLEZ M (2004) Genetic variation among seven strains of Dunaliella salina (Chlorophyta) with industrial potential, based on RAPD banding patterns and on nuclear ITS rDNA sequences. Aquaculture 233: 149-162

GÓMEZ P, GONZÁLEZ M, BECERRA J (1999) Quantity and quality of $\beta$-carotene produced by two strains of Dunaliella salina (Teodoresco 1905) from the North of Chile. Bol Soc Chil Quím 44: 463-468

GONZÁLEZ M, COLEMAN AW, GÓMEZ P, MONTOYA R (2001) Phylogenetic relationship among various strains of Dunaliella (Chlorophyceae) based on nuclear ITS rDNA sequences. J Phycol 37: 604-611

GONZÁLEZ MA, GÓMEZ P, MONTOYA R (1999) Comparison of PCR-RFLP analysis of the ITS region with morphological criteria of various strains of Dunaliella. J Appl Phycol 10: 573-580

HEBER D (2000) Colorful cancer prevention: Alphacarotene, lycopene, and lung cancer. Am J Clin Nutr 72: 901-902

JIMÉNEZ C, PICK U (1993) Differential reactivity of $\beta$ carotene isomers from Dunaliella bardawil toward oxygen radicals. Plant Physiol 101: 385-390

JIMÉNEZ C, PICK U (1994) Differential stereoisomer compositions of $\beta, \beta$-carotene in thylakoids and in pigment globules in Dunaliella. J Plant Physiol 143: 257-263

LERS A, BIENER Y, ZAMIR A (1990) Photoinduction of massive $\beta$-carotene accumulation by the alga Dunaliella bardawil. Kinetics and dependence on gene activation. Plant Physiol 93: 389-395

LERS A, LEVY H, ZAMIR A (1991) Co-regulation of a gene homologous to early light-induced genes in higher plants and $\beta$-carotene biosynthesis in the alga Dunaliella bardawil. J Biol Chem 266: 13698-13705

LEVIN G, MOKADY S (1994) Antioxidant activity of 9cis compared to all-trans $\beta$-carotene in vitro. Free Radic. Biol Med 17: 77-82

LEVY J, BOSIN E, FELDMAN B, GIAT Y, MIINSTER A, DANILENKO M, SHARONI Y (1995) Lycopene is a more potent inhibitor of human cancer cell proliferation than either $\alpha$-caroteno or $\beta$-caroteno. Nutrition and Cancer 24: 257-266

LEVY H, TAL T, SHAISH A, ZAMIR A (1993) Cbr, an algal homolog of plant early light induced proteins, is a putative zeaxanthin binding protein. J Biol Chem 268: 20892-20896

MARKOVITS A, GIANELLI MP, CONEJEROS R, ERAZO S (1993) Strain selection for $\beta$-carotene production by Dunaliella. World Journal of Microbiology and Biotechnology 9: 534-537 
MICHAUD D, FESKANICH D, RIMM E, COLDITZ G, SPEIZER F, WILLET W, GIOVANNUCCI E (2000) Intake of specific carotenoids and risk of lung cancer in 2 prospective US cohorts. Am J Clin Nutr 72: 990-997

MC LACHLAN J (1973) Growth media marine. In: STEIN JR (ed) Handbook of Phycological Methods. Culture methods and growth measurements. London: Cambridge University Press. pp: 25-51

MURAKOSHI M, NISHINO H, SATOMI Y, TAKAYASU J, HASEGAWA T, TOKUDA H, IWASHIMA A, OKUZUMI J, OKABE H, KITANO H, IWASAKI R (1992) Potent preventive action of $\alpha$-carotene against carcinogenesis: Spontaneous liver carcinogenesis and promoting stage of lung and skin carcinogenesis in mice are suppressed more effectively by $\alpha$-carotene than by $\beta$-carotene. Cancer Research 52: 6583-6587

ORSET S, YOUNG A (1999) Low temperature induced synthesis of $\alpha$-carotene in the microalga Dunaliella salina (Chlorophyta). J Phycol 35: 520-527
ORSET S, YOUNG A (2000) Exposure to low irradiances favors the synthesis of 9-cis $\beta, \beta$-carotene in Dunaliella salina (Teod.). Plant Physiol 122: 609-617

PALOZZA P, KRINSKY N (1992) Antioxidant effects of carotenoids in vivo and in vitro: An overview. Meth Enzymol 213: 403-420

PARRA OO, FLOYD GL, WILCOX LW (1990) Taxonomic identification and ultrastructural characterization of a Chilean strain of Dunaliella. Rev Chilena Hist Nat 63: 239-245

RISACHER F, ALONSO H (1996) Geoquímica del Salar de Atacama, parte 2: Evolución de las aguas. Revista geológica de Chile 23: 123-134

WEGMANN K, METZNER H (1971) Synchronization of Dunaliella salina cultures. Archiv für Mikrobiologie 78: $360-367$

YUEN C (1994) Palm oil carotenoids. Food and Nutrition Bulletin 15: 130-137 